Artikel

\title{
The Maturity Level of IT Governance Based On Cobit Framework 4.0 on DS and ME Domains at PT. Milano Mitra Abadi
}

\section{Teofilus Sunarsa}

Universitas Buddhi Dharma, Information System, Banten, Indonesia

\begin{tabular}{|c|c|}
\hline SUBMISSION TRACK & $A B S T R A C T$ \\
\hline $\begin{array}{l}\text { Received } 20 \text { June } 2018 ; \\
\text { Revised } 20 \text { July } 2018 ; \\
\text { Accepted } 10 \text { September } 2018 ; \\
\text { Available online } 20 \text { September } 2018\end{array}$ & \multirow{5}{*}{$\begin{array}{l}\text { PT. Milano Mitra Abadi is a retail company engaged in the } \\
\text { fashion and shoes in the business process is not separated } \\
\text { from the use of IT. IT is an effective step taken by the } \\
\text { company to develop its business in order to provide a level of } \\
\text { efficiency and effectiveness in the management of sales data } \\
\text { or inventory data with good and orderly. } \\
\text { One of the tools used for IT Governance is COBIT (Control } \\
\text { Objectives for Information and Related Technology) is a } \\
\text { standard model that provides documentation of best IT } \\
\text { management practices that can help management and user To } \\
\text { bridge the gap between business risks, control needs, and } \\
\text { technical problems. The analysis for the maturity level is } \\
\text { done by comparing the level of maturity that exists at the } \\
\text { moment with the level of maturity. The level of maturity that } \\
\text { is intended on the basis represents the level of maturity of the } \\
\text { industry average at level } 3 \text {. Current level of maturity (current } \\
\text { maturity level) for each process that is in the domain of } \\
\text { Deliver and Support and Monitor and Evaluate is almost } \\
\text { entirely at level } 2 \text {. This can be said that the process of IT } \\
\text { governance in PT. Milano Mitra Abadi has been done but has } \\
\text { not been running optimally, has a pattern that is repeatedly } \\
\text { done in conducting activities management related to } \\
\text { technology governance Information, but its existence has not } \\
\text { been well-defined and formal so that there is still an } \\
\text { inconsistency. It is recommended that the evaluation of IT } \\
\text { can be done routinely every specific time period } \\
\text { (periodically) so that the desired level of maturity can be } \\
\text { achieved and performed by a specific unit. }\end{array}$} \\
\hline KEYWORD & \\
\hline $\begin{array}{l}\text { IT Governance, Domain Deliver and Support, } \\
\text { Domain Monitor and Evaluate, Current } \\
\text { Maturity Level, Expected Maturity Level }\end{array}$ & \\
\hline KORESPONDENSI & \\
\hline E-mail:sunarsa_teofilus@yahoo.com & \\
\hline
\end{tabular}

\section{INTRODUCTION}

IT utilization in the world of retail business is now a very important thing for companies in general. IT can provide the opportunity to transform and increase sales to a retail business. IT implementation requires considerable cost with no small risk of failure. Application of IT to a company can be used to the fullest, therefore it takes a precise understanding of the basic concepts of the prevailing system, the technology utilized, applications used and the management and development of IT systems Done. 
PT Milano Mitra Abadi is a shoe retail company that utilizes IT in running its business. Considerable sales and increased customer development and ongoing business competition will demand the right decision making and can be achieved when information is obtained quickly and accurately. This is what happened to PT. Milano Mitra Abadi, which is information about the things on the day that has been run can be known at the end of the day and will be used as a reference in making the decision for business continuity on the day Next.

To see the importance of information in PT. Milano Mitra Abadi, IT needs to be considered. PT. Milano Mitra Abadi must be able to minimize the risk by doing IT management properly and properly.

In order to manage IT management in PT. Milano Mitra Abadi can take place effectively, the organization needs to assess the extent to which IT is now ongoing and identify the improvements that can be made. This applies to all managed processes contained in it and the IT management process itself. The use of Maturity Model (maturity) In this case will facilitate the assessment by way of approach that is structured towards a scale that is easy to understand and consistent.

One of the tools used for IT management is COBIT (Control Objectives for Information and Related Technology) which is a standard model that provides documentation of best IT management practices that can help management and user To bridge the gap between business risks, control needs, and technical problems.
Based on the above and based on the planning of development strategy in PT. Milano Mitra Abadi, the PT. Milano Mitra Abadi needs to implement IT management to the information system of PT. Milano Mitra Abadi using the framework COBIT version 4.0 is especially for Deliver and Support (DS) and Monitor and Evaluate (ME) domains.

\section{LITERATURES REVIEW}

The governance of Information technology (IT Governance) is a topic that began to be crowded since the 90 's. Many companies are competing to apply this topic to companies alongside their existing company policies. The use of this information technology governance itself becomes unstandardized as the business grows in every company. Therefore, many experts start to think about making a change and standardizing the governance of such information technology [1].

With the change that occurs against the governance of IT then it is formulated that this governance can be integrated with COBIT which then become one of the framework in the IT governance itself. This cobit will be able to measure the IT governance of a company either in process measurement or material measurements that provide a return value called maturity level and divided into four domains.

Thus, IT can be measured by COBIT which has four domains to determine the level of maturity levels occurring in each domain. 


\section{FRAMEWORK}
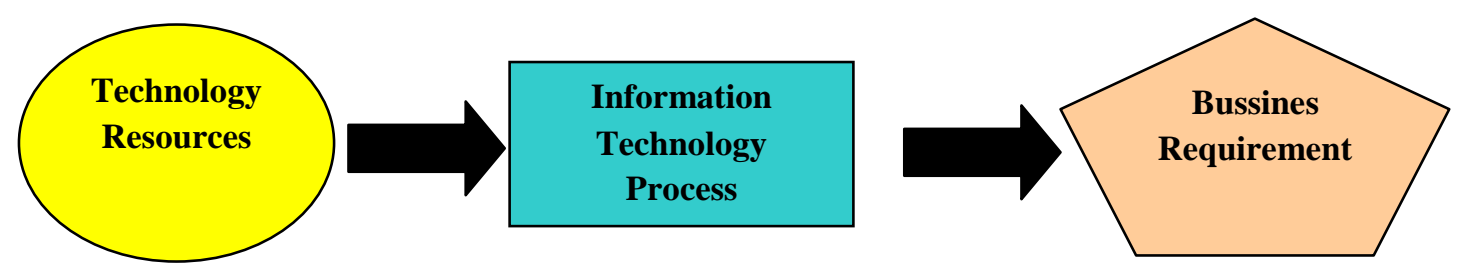
- Data
- Application
- Technology
- Facility
- Man Power

\section{- Planning and Organizing \\ - Aquistion and Implementation \\ - Support \\ - Monitoring and Evaluate}

- Efective

- Efeciency

- Secret

- Integrity

- Availability

- Objectiveness

- Information

\section{Domains}

Domain DS

DS1 - Define and manage service levels.

DS2 - Manage third-party services.

DS3 - Manage performance and capacity.

DS4 - Ensure continuous service.

DS5 - Ensure systems security.

DS6 - Identify and allocate costs.

DS7 - Educate and train users.

DS8 - Manage service desk and incidents.

DS9 - Manage the configuration.

DS10 - Manage problems.

DS11 - Manage data.

DS12 - Manage the physical environment.

DS13 - Manage operations

\section{Domain ME}

ME1 - Monitor and evaluate IT performance.

ME2 - Monitor and evaluate internal control.

ME3 - Ensure regulatory compliance.

ME4 - Provide IT Governance.

Figure 1. COBIT Framework 


\section{METHODS}

The research tool that authors use in assisting the research process is to use the questionnaire that was taken based on the literature that existed in COBIT version 4 [2], on DS and ME domains for each Control Its Objective. The reasons for the underlying use of such research tools are as follows:

A. Questionnaire is one of the research tools that can be used for research survey approach

B. The population of respondents used in this research is to have authority over IT in PT. Milano Mitra Abadi

C. The distribution of the questionnaire is done directly to the respondent by providing guidance to fill the questionnaire, so expect the research results are more accurate and describes the overall state of the population [3].

D. Collecting the respondents directly to provide explanation of filling, foreign terms and appropriate input that can be understood by each Responden [5]

E. Analysis for maturity is done by comparing the current level of maturity with the level of the intended maturity. The level of maturity on the base is the average maturity level of the industry [2] which is at level 3 and above (3.7) F. The gap between the current obtained with the addressable is an indicator in the formulation of the recommendation of governance improvement [4]

The drafting of the questionnaire was done by providing questions for each maturity level in the DS and ME COBIT domain version 4.0, and each Control Objective in the DS and ME domains consisted of 5 levels with the order from level 0 to level 5. Each Control Objective domain DS and ME at each level has several questions, so that each Control Objective in the DS and ME domains has many questions, for the number of questions on each Control Objective on the domain DS and ME [2]

\section{RESULT}

In general, it can be seen from the result of calculation of maturity level (maturity level) of IT governance for information System PT. Milano Mitra Abadi which can be seen in Appendix 4. In the Table 1. and the following Table 2. will be presented with the recapitulation of the maturity level (maturity level) for the DS and ME domains.

Table 1.

Maturity Level Deliver and Support

\begin{tabular}{|c|l|c|}
\hline Domain & \multicolumn{1}{|c|}{ Proses } & $\begin{array}{c}\text { Current } \\
\text { Maturity }\end{array}$ \\
\hline DS1 & $\begin{array}{l}\text { Define and manage service } \\
\text { levels }\end{array}$ & 2,860 \\
\hline DS2 & Manage Third Party Services & 3,024 \\
\hline DS3 & $\begin{array}{l}\text { Manage performance and } \\
\text { Capacity }\end{array}$ & 2,641 \\
\hline DS4 & Ensure continous service & 2,731 \\
\hline DS5 & Ensure systems security & 2,909 \\
\hline DS6 & Identify and allocate cost & 4,238 \\
\hline DS7 & Educate and train user & 2,680 \\
\hline DS8 & Assist and advice customer & 2,707 \\
\hline DS9 & Manage the configuration & 2,782 \\
\hline DS10 & $\begin{array}{l}\text { Manage problems and } \\
\text { incidents }\end{array}$ & 2,953 \\
\hline DS11 & Manage data & 2,965 \\
\hline DS12 & Manage facilities & 2,722 \\
\hline DS13 & Manage operations & 3,168 \\
\hline
\end{tabular}

Table 2 .

Maturity Level Monitor and Evaluate

\begin{tabular}{|l|l|c|}
\hline Domain & \multicolumn{1}{|c|}{ Proses } & $\begin{array}{c}\text { Current } \\
\text { Maturity }\end{array}$ \\
\hline ME1 & $\begin{array}{l}\text { Monitor and evaluate IT } \\
\text { performance }\end{array}$ & 2,967 \\
\hline ME2 & $\begin{array}{l}\text { Monitor and evaluate internal } \\
\text { control }\end{array}$ & 2,444 \\
\hline ME3 & $\begin{array}{l}\text { Monitor and evaluate ensure } \\
\text { regulatory compliance }\end{array}$ & 2,747 \\
\hline ME4 & $\begin{array}{l}\text { Monitor and evaluate provide } \\
\text { IT Governance }\end{array}$ & 2,695 \\
\hline
\end{tabular}


Table 3.

Resume Current Maturity ofInformation System PT Milano Mitra Abadi in DS and ME Domains

\begin{tabular}{|l|c|c|c|}
\hline \multirow{2}{*}{$\begin{array}{c}\text { Maturity } \\
\text { Level }\end{array}$} & DS & ME & $\begin{array}{c}\text { DS dan } \\
\text { ME }\end{array}$ \\
\cline { 2 - 4 } & 2,952 & 2,714 & 2,833 \\
\hline Rata-rata & 2,641 & 2,444 & 2,444 \\
\hline Minimal & 4,238 & 2,967 & 4,238 \\
\hline Maksimal & & & \\
\hline
\end{tabular}

From the Table 3. can be seen that the current level of maturity (current maturity level) for each process in the domain Deliver and Support and Monitor and Evaluate almost as a whole is around Level 2 (repeatable). This can be said that the process of IT governance in PT. Milano Mitra Abadi has been done but has not been running optimally, has a pattern that is repeatedly done in conducting activities management related to technology governance Information, but its existence has not been well-defined and formal so that there is still an inconsistency.

While from Table 1 and Table 2 maturity level (maturity level) domain Deliver and Support and Monitor and Evaluate, it will be created representation in radar chart, as seen in Figure 2. and Figure 3. as follows:

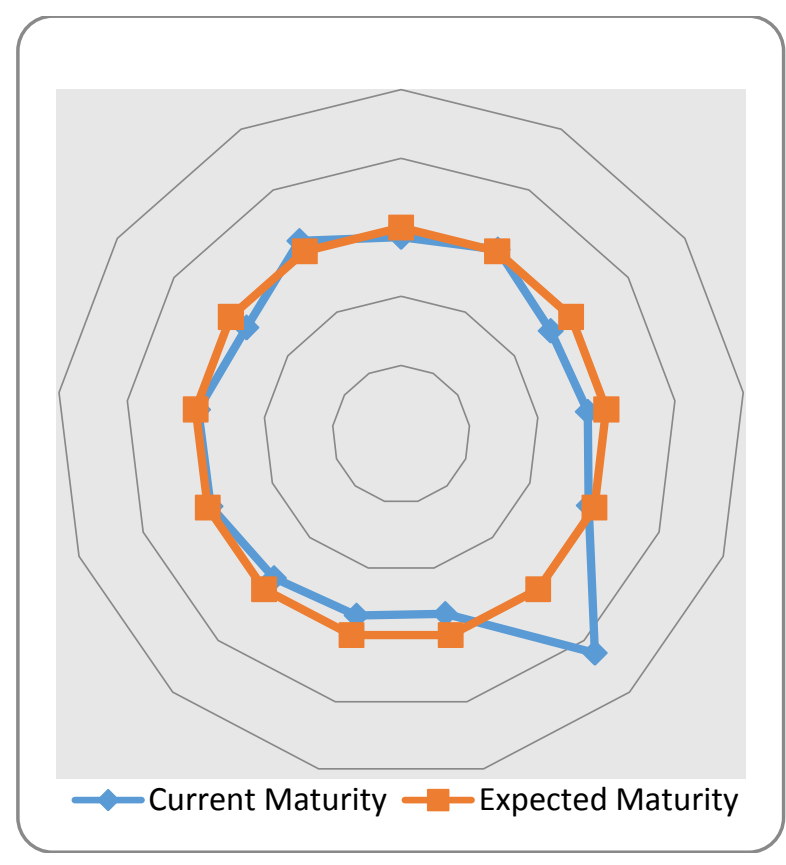

Figure 2.

Current maturity level vs Expected maturity level pada domain Deliver and Support Sistem Informasi PT. Milano Mitra Abadi

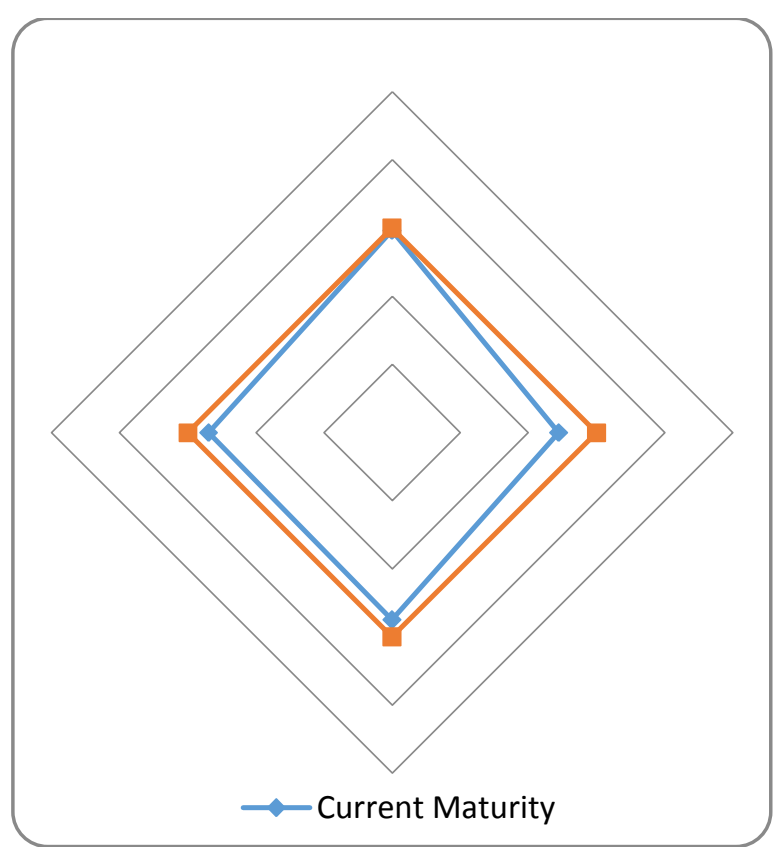

Figure 3.

Current maturity level vs Expected maturity level pada domain Monitor and Evaluate Sistem Informasi PT. Milano Mitra Abadi 


\section{DISCUSSION}

It is known that information is very important for management in decision making. Information is obtained from information system or also called processing systems or information processing systems or information-generating systems. Information Systems is a system in an organization that brings together the needs of daily transaction processing, supporting Operations, managerial and strategic activities of an organization and providing certain outside parties with the necessary reports [6].

To determine the processes of IT governance and ensure that the results are achieved optimally so the management requires the planning and implementation stages of the IT governance as follows.

A. Identifying needs (identify needs). Need to first understand the background of the IT Governance Development Initiative, understand business objectives mapped towards IT governance, understand the potential risks that will affect the organizational goals and the next is to determine the domain or Scope of the process to be managed [7].

B. Predicting solution (envision solution). Describing the maturity of existing IT processes, targets to be achieved and analyzes gaps between them.

C. Plan solution (Plan solution). Identify possible process initiatives that will be managed and make proposed solutions that are integrated with business objectives [8].

D. Implementing solution (Implementation solution). Implementation, monitoring, evaluation as feedback and learning for continuous improvement.

\section{CONCLUSION}

Some conclusions that can be taken from the studies that have been conducted are as follows:

1. The information system IT governance of PT. Milano Mitra Abadi has been done although it still has not run optimally because it has not reached the level of maturity expected.

2. The level of maturity (maturity level) existing in each IT process contained in the domain Delivery and Support (DS) and Monitor and Evaluate (ME) average at the level 2.833 and still be at level 2 (repeatable but intuitive).

3. To be able to achieve the desired maturity level (expected maturity level) in Level 3 (defined process) then all the required procedures in each process must be fulfilled.

4. To reach level 3 (defined process), referring to standardization COBIT then each organization must have a clear mechanism and procedure regarding the procedures and management of the investment process of information technology, and communicate and Well throughout the organization's management range.

5. The IT governance process at PT. Milano Mitra Abadi has a pattern that is repeatedly conducted in conducting activity management related to the governance of information technology, but its existence has not been well-defined and formal so that still An inconsistency.

6. Although the information system of PT. Milano Mitra Abadi just run for 2 years, it turns out that all processes still need to be repaired even to the handling of the superpriority. 


\section{REFERENCES}

[1] Indrajit, Richardus Eko. Kajian Strategis Analisa Cost-Benefit Investasi Teknologi Informasi, 2006

[2] IT Governance Institute, “COBIT 4.0”, 2005

[3] Peterson, R. R., "Integration Strategies and Tactics for Information Technology Governance" dalam "Strategies for Information Technology Governance", Idea Group Inc., 2004.

[4] Alvin A, Arens, James K.Loebbecke, “Auditing”, Edisi Indonesia, Jakarta, 2003.

[5] Weill, Peter dan Jeanne W. Ross, "IT Governance on One Page" dalam MIT Sloan Working Paper No. 4517-04; CIS Research Working Paper No. 349, Massachusetts Institute of Technology (MIT) - Sloan School of Management, November 2004.

[6] Weill, P. \& Ross (2004) J.W., "IT Governance, How Top Performers Manage IT Decision Rights for Superior Results", Harvard Business School Press, Boston.

[7] Sarwosri dan Djiwandou Agung Sudiyono Putro, "Designing and Making of Audit IT System Software Based on CoBIT Framework 4.1” ISSN 2085 1944, Institut Teknologi Sepuluh Nopember. 2008

[8] IT Governance Institute, “COBIT 4.0”, 2005

\section{BIOGRAPHY}

Teofilus Sunarsa. Was born in Tangerang, Banten, November $1^{\text {st }} 1985$. Started education at STMIK Buddhi Tangerang in 2008 for Bachelor Degree in Information of Technology. After graduated from STMIK Buddhi, registered in School of Technology Eresha for Master Degree in Management Information System. And now as a lecture at Buddhi Dharma University in Information System Department. 